\title{
PECULIARITIES OF FORMATION OF MARKETING STRATEGY IN THE SPHERE OF SERVICES OF THE REPUBLIC OF UZBEKISTAN
}

\author{
M.M. Ziyayeva \\ Tashkent State University of Economics \\ 49, Islom Karimov, Tashkent, 100003, Republic of Uzbekistan
}

\begin{abstract}
This paper reviews the methodological aspects of shaping marketing strategy in service sector. In addition, in order to classify main types of marketing, there has been provided the review of theoretical and empirical literature on the subject. Review has shown that there are vast variety of factors such as social environment, market constraints, people's behavior, time prospective, managers' focus, market structure, degree of societies advancement, and etc. which can influence on shaping marketing strategy.
\end{abstract}

Key words: marketing strategy, marketing in service sector, marketing of services in Uzbekistan, comparison of marketing strategies

\section{Introduction}

Uzbekistan's Five-Area Development Strategy for 2017-2021 stipulates the need to "Enhance the competitiveness of the national economy by deepening structural transformations, modernizing and diversifying its leading industries: increasing the share of industry and services in its structure". The service sector is currently undergoing serious transformations, when the traditional methods of doing business are replaced by new ones, such as information and communication technologies, tourism, consulting, recruiting, etc. Introduction of more and more advanced technologies into the service processes and carefully designed service systems which meets the needs of consumers, serves for the growth of competitiveness of companies in new industrial and regional service markets.

\section{Literature review}

Under the marketing concepts, services represent a huge variety of activities, works and occupations. In defining the service, Kotler notes "A service is any event, activity or benefit that one of the parties can offer to the other party and which is mostly intangible and does not lead to possessing of anything. The production of services may or may not be related to the product in its tangible form" (Kotler, 2012). Based on the research of the intra-organizational communication processes and the concept of affairs marketing, Kotler suggested to distinguish three interrelated units in services marketing:

- organization, or top management, service firms; 
- contact personnel of the service firm;

- consumers of services.

Until recently, the concept of service productivity has been theoretically under developed (Corsten, 2001). Generally, transferring the traditional understanding of productivity from manufacturing and producing material goods to services is not very successful due to immateriality as well as intangibility of services (Corsten, 2001). Immateriality is connected with both the intangibility of the output, as well as the heterogeneity of services. Moreover, the integration and involvement of people in the value adding processes is the main point to services (Lasshof, 2006). According to $G$. Assel, services are intangible benefits that are acquired by the consumer, but are not related to property. Analyzing this definition it becomes obvious that G. Assel connects the service with a certain final result (blessing), and only the acquisition of the item appears from the actions, which in principle refers to the service itself, because it is connected, rather, with the consumer (Assel, 1999). This means that the customer is obviously a key factor for service providers that must also somehow be connected and accounted for in the concept of services productivity. Nevertheless, it has contradictory points that the customer usually is not an integral part during value creation and the business processes known as a closed system (Grönroos and Ojasalo, 2004). According to N.V. Mironova, there are certain reasons that make it difficult to formulate a unified approach to the definition of the term "service": - services include all economic benefits that can not be attributed to agriculture or industrial production; - the services include numerous and various actions aimed at various objects; - these numerous and diverse actions refer to the existing official statistics to one class of economic goods; - service a flexible object whose boundaries are easily changed (Mironova, 2003). How are services defined and how can they best be delivered in different cultures throughout the world is one of the questions that, according to Ben Schneider, should usefully be asked to bring a new twist to the international issue of services marketing (Schneider, 2000).

In order to effectively manage marketing in a service firm, the manager needs to develop three strategies aimed at these three links.

1. The strategy of traditional marketing is aimed at the link "consumer-organization" and is related to issues of pricing, communications and distribution channels.

2. The strategy of internal marketing is aimed at the "organization-personnel" link and is associated with staff motivation.

3. The strategy of interactive marketing - on the link "personnel - consumer" and is associated with quality control of the provision of services.

The main component of the modern marketing structure is, first of all, foresight, that is strategies and plans on the basis of which the marketing activity is built (Table 1).

Table 1

Structure of modern marketing

\begin{tabular}{|l|l|}
\hline \multicolumn{1}{|c|}{ Title } & \multicolumn{1}{c|}{ Content } \\
\hline Social marketing & $\begin{array}{l}\text { Represents the meaning of a significant expansion of the scope of marketing activities. } \\
\text { Its subject is not only the market, but also social activities }\end{array}$ \\
\hline Global marketing & $\begin{array}{l}\text { Exploring and specific commercial operations related to international trade, tourism } \\
\text { and other forms of cooperation between countries }\end{array}$ \\
\hline Macro marketing & Manages the market to meet the needs of end-users \\
\hline
\end{tabular}


End of table 1

\begin{tabular}{|l|l|}
\hline \multicolumn{1}{|c|}{ Title } & \multicolumn{1}{c|}{ Content } \\
\hline Consumerism & Creation and implementation of the system of consumer rights protection \\
\hline Behaviorism & $\begin{array}{l}\text { The direction of marketing, specializing in studying the psychological origins of } \\
\text { consumer behavior in the process of selecting and acquiring goods or services, } \\
\text { revealing their preferences }\end{array}$ \\
\hline Micromarketing & $\begin{array}{l}\text { Performs management within the enterprise, the functioning of which ensures } \\
\text { communication between the producer and the consumer }\end{array}$ \\
\hline Functional marketing & $\begin{array}{l}\text { Performs an element-wise analysis of the organization's sales activities, namely } \\
\text { wholesale distribution, transportation, storage }\end{array}$ \\
\hline $\begin{array}{l}\text { Marketing of consumer } \\
\text { goods }\end{array}$ & $\begin{array}{l}\text { Comprehensively studies the consumer, his needs, requests, as well as the factors } \\
\text { and conditions under which they are formed and develop }\end{array}$ \\
\hline Strategic marketing & $\begin{array}{l}\text { Studying the ratio of external factors and internal resources, the capabilities of the } \\
\text { firm, taken into account when making management decisions }\end{array}$ \\
\hline Institutional Marketing & Final sale of production and retail. The focus is on working with a retailer \\
\hline Product marketing & $\begin{array}{l}\text { Carefully studies consumer preferences, taking into account which the development } \\
\text { of products and their modernization }\end{array}$ \\
\hline Managerial Marketing & $\begin{array}{l}\text { Spreads the principles of marketing to all levels of enterprise management from the } \\
\text { bottom to the top }\end{array}$ \\
\hline
\end{tabular}

Source: Compiled by the author.

Until recently, service organizations were inferior to firms in terms of the intensity of marketing use. Today, when competition increases, increase costs, while productivity and quality become key performance indicators, there is a need for more complex marketing decisions. Service organizations today faced with three main marketing challenges: they want to increase their competitive differentiation, the quality of services and productivity. Marketing management is defined as "... analyzing, planning, implementation and monitoring the implementation of activities designed for establishing, strengthening and maintaining of profitable exchanges with targetyв customers for achieving specific organizational goals such as profit, sales, market share etc.” (Gaydaenko, 2006).

The marketing strategy represents the procedure for analyzing the potential of the company and its objective opportunity in the market, selecting the system of organization's goals, developing plans aimed at reducing risk and providing long-term and sustainable prosperity of the company. The main difference between a simple long-term plan and a strategy is that the strategy should create conditions under which the company will avoid problems in the market. Strategic marketing management includes the process of developing and maintaining the compliance of the strategy and the organizational and functional potential of the firm to external conditions, and realized on the basis of the study of the need. The main task solved in the framework of strategic marketing is the orientation of the enterprise in the external environment (Walker O., Jr. Boyd H., Larshe J.-K, 2006).

There are many different types of marketing strategies, each has its own mission in the enterprise. Let's compare some of them (Table 2).

Marketing strategy is one of the main components of the overall strategy of the organization, growth of the enterprise, its prospects, and sometimes its existence. The base of the strategy, aimed at achieving established goals is based on selection of the target segment or market segments and distinctive advantages. These two elements constitute a strategy for positioning a firm or brand. 


\section{Different types of marketing strategies}

\begin{tabular}{|c|l|l|}
\hline № & \multicolumn{1}{|c|}{ Title } & \multicolumn{1}{c|}{ Content } \\
\hline 1 & $\begin{array}{l}\text { Organization's Growth } \\
\text { Strategy }\end{array}$ & $\begin{array}{l}\text { It is medium term prospect of organization's activity. By planning growth, first } \\
\text { of all, revealed the appropriateness of acquisitions or internal development }\end{array}$ \\
\hline 2 & $\begin{array}{l}\text { Strategy for internal } \\
\text { development }\end{array}$ & $\begin{array}{l}\text { This strategy implies penetration of the market, and contributes for the expansion } \\
\text { of markets and development of products }\end{array}$ \\
\hline 3 & Penetration strategy & $\begin{array}{l}\text { Presents already existing brands to the market with making allowance to existing } \\
\text { markets }\end{array}$ \\
\hline 4 & $\begin{array}{l}\text { Market expansion } \\
\text { strategy }\end{array}$ & Assumes the promotion of goods and services to new markets \\
\hline 5 & $\begin{array}{l}\text { Product development } \\
\text { strategy }\end{array}$ & $\begin{array}{l}\text { Provides emergence or expansion of existing goods or services, mainly in the } \\
\text { existing market }\end{array}$ \\
\hline 6 & $\begin{array}{l}\text { Strategies for external } \\
\text { acquisitions }\end{array}$ & $\begin{array}{l}\text { Comprises of company's growth strategy based on internal development and } \\
\text { growth strategy through external acquisitions }\end{array}$ \\
\hline
\end{tabular}

Source: Compiled by the author.

A marketing strategy is a plan, which can be modified as situations progress. It is the strategic plan that allows the company to define its specific goals, objectives, that it seeks and how to develop.

The starting point of designing a marketing strategy is the analysis of market development and forecasting of further development of the market environment. It includes: macro segmentation and micro segmentation, that is, an assessment of the competitive advantages and competitiveness of the company, its products and services on the market, an assessment of the attractiveness of selected product markets and their individual segments, the possibility of expanding the geography of sales.

Thus, strategic management involves implementation of a strategic marketing plan that includes the benchmarks for the organization's long-term prosperity and the entire range of products and services provided. Having chosen the target market and strategy of its coverage, it is necessary to implement the procedure for positioning its services. Positioning services is an action that completes a set of actions to ensure the competitiveness of their services by choosing the most effective type of marketing behavior in specific conditions.

One of the main principles of strategic marketing of the service sector is the principle of complexity, which regards it as a systemic unity of actions carried out in the following areas:

- improvement of services and enrichment of the assortment line through the constant development and introduction of new types of services;

- realization of price policy with the aim of balancing supply and demand;

- improving methods and methods of marketing services;

- establishment of appropriate proportionality in the use of different distribution channels;

- improvement of communication links with the consumer in order to stimulate sales of services and effective use of means of advertising impact.

The operation of this principle, traditional for strategic planning in general, has a specific essence in the marketing of services. In this area there is an advantage of the territorial aspect over the sectoral aspect, since the demand for services is formed mainly 
under the influence of territorial features in the way of life of the population and its territorial structure, and the marketing task is to bring the development of service industries in line with existing demand.

The strategy of promotion of services consists of four means of influencing the consumer:

- advertising;

- methods of sales promotion;

- publicity and public relations;

- technologies of personal sales.

In the marketing of services, there is a system of strategic planning, which also has some peculiarities. The sequence of planning stages and promotion strategies are similar both for the manufacturing sector and for the service sector. They include determining the objectives of promotion, selecting target audiences and determining the budget for each of the four means of impact on the consumer. However, in view of the distinctive characteristics of the service as a commodity, the content of these stages significantly differs while planning a promotion strategy in marketing services. The main difference is in strategic focus of the promotion strategy for goods and services.

\section{Marketing of services in Uzbekistan}

In order to ensure balanced development and diversification of the activity of service enterprises, raising competitiveness and quality of their services, there were adopted Resolutions of the President of the Republic of Uzbekistan "About the program of development of the services sector in the Republic of Uzbekistan for 2012-2016", and the Cabinet of Ministers of the Republic of Uzbekistan "About the program for the development of the services sector for 2016-2020" and etc.

Priority directions and tasks in development of the service sector in the Republic of Uzbekistan for 2016-2020 were set:

- raising GDP through development of the services sector, and bringing its share in the national economy up to 48.7 percent;

- raising volume of services in rural areas by 1.8 times by 2020 ;

- creation of conditions for accelerated development of the service sector, structural reforms through the expansion of engineering, communication, road and transport infrastructure, introduction of modern information and communication technologies in the sectors;

- shaping competitive environment, assistance to the development of small and private business entities;

- expansion of various innovative services, new communication facilities;

- provision of technical accessibility of the population to the telecommunications network, providing quality services on their basis, complete transition to digital telephone communication and television systems, bringing the share of communication and information services in the economy up to 2.5 percent by year 2020 ;

- the development of financial services with the introduction of the newest electronic payment technologies;

- further development of high-tech in healthcare services. 
The development of services sector in Uzbekistan causes an increase in the share of services in the GDP and growth of competition in the services market (Fig. 1).

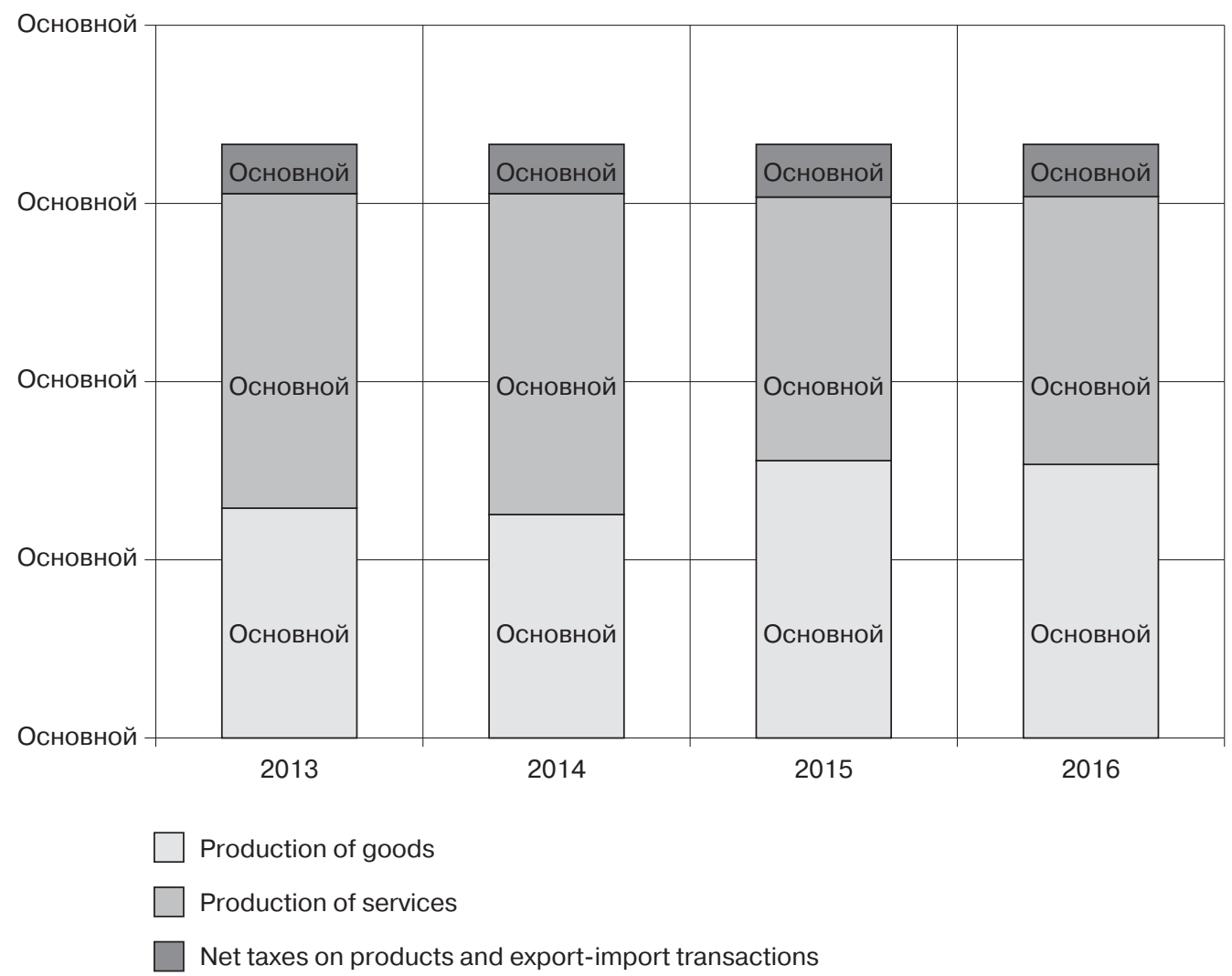

Fig. 1. The structure of GDP

Source: Uzbekistan in figures (2017). State Committee of the Republic of Uzbekistan on Statistics. 45 p.

As a result of targeted, comprehensive measures on diversification and structural transformation of the economy, the share of services in GDP increased from 38.7 percent in 2005 to 45.2 percent in 2016. Modern high-tech and market-oriented types of servicesinformation-communication, banking, insurance, leasing, tourist-excursion and others are developing at an accelerating rate.

Among the main driving factors of competition in the domestic services market, following are distinguished (Table 3).

Table 3

Classification of competition factors in the services market of the Republic of Uzbekistan

\begin{tabular}{|l|l|}
\hline \multicolumn{1}{|c|}{ Title } & \multicolumn{1}{c|}{ Content } \\
\hline $\begin{array}{l}\text { Growth of the number of } \\
\text { economic entities }\end{array}$ & $\begin{array}{l}\text { Growth in quantity of economic entities in the banking, insurance, and trade } \\
\text { spheres objectively leads to the expansion of product supply in the services } \\
\text { sectors, which compete with each other }\end{array}$ \\
\hline $\begin{array}{l}\text { Liberalization of prices and } \\
\text { the transformation of the } \\
\text { economy }\end{array}$ & $\begin{array}{l}\text { The abolition of direct price controls on wholesale and retail prices has become } \\
\text { a stimulus to the price competition. The development of the business environment } \\
\text { is reflected in the stabilization of the profitability of the business, which in turn } \\
\text { leads to increased competition }\end{array}$ \\
\hline
\end{tabular}


End of table 3

\begin{tabular}{|l|l|}
\hline \multicolumn{1}{|c|}{ Title } & \multicolumn{1}{c|}{ Content } \\
\hline $\begin{array}{l}\text { Liberalization of foreign } \\
\text { economic relations }\end{array}$ & $\begin{array}{l}\text { This led to appearance in the domestic market of new foreign competitors, which } \\
\text { have extensive experience and knowledge in the field of competition }\end{array}$ \\
\hline $\begin{array}{l}\text { Structural reorganization of } \\
\text { the industrial markets }\end{array}$ & $\begin{array}{l}\text { The advancing growth of the services sector, as well as the profitability of trade } \\
\text { and financial operations, also influenced the intensification of competition }\end{array}$ \\
\hline $\begin{array}{l}\text { Provision of convertibility of } \\
\text { national currency }\end{array}$ & $\begin{array}{l}\text { The transition to convertibility of the national currency had great impact for the } \\
\text { development of competition processes. The most benefits from the convertibility } \\
\text { of sums have gained mainly businesses operating for the export, as well as } \\
\text { companies with foreign capital participation due to price competition and the } \\
\text { relatively high quality of the goods and services offered }\end{array}$ \\
\hline $\begin{array}{l}\text { Formation of the private } \\
\text { sector of the economy }\end{array}$ & $\begin{array}{l}\text { The private sector of the economy creates additional conditions for the development } \\
\text { of competition and in many branches of the service sector begins to play a } \\
\text { dominant role (trade, mobile communications, insurance, tourism, etc.) }\end{array}$ \\
\hline $\begin{array}{l}\text { Demonopoliza-tion of the } \\
\text { economyand development } \\
\text { of competition }\end{array}$ & $\begin{array}{l}\text { Privatization of state organizations, industrial and regional demonopolization } \\
\text { programs, state regulation of natural monopolies, stimulation of the development } \\
\text { of small businesses and private entrepreneurship, and other measures leads to } \\
\text { increased competition in the services market }\end{array}$ \\
\hline Institutional reforms & $\begin{array}{l}\text { Creation and development of market institutions of stock-exchanges, banks, } \\
\text { insurance companies, IT companies and other organizations - contributed to the } \\
\text { formation of market infrastructure and exacerbated competition in the services } \\
\text { sector }\end{array}$ \\
\hline
\end{tabular}

Source: Compiled by the author

\section{Conclusion}

The services sector and service as a rather complex social phenomenon are objects of study of various sciences: economics, marketing, management, sociology, law, informatics, psychology and others. Within the framework of research paradigms, each of which actualizes certain aspects of services, that are most significant for a particular scientific field, principles and technologies for interaction between the producer and consumer of the service are developed, and effective mechanisms for such interaction are identified. However, it should be noted that at present there is no complete theory of services that would systematize existing methodological and practical approaches to the study and management of this field. In this case, there are basically formulated a number of theoretical provisions that illuminate the phenomenon under study from different points of view. The development of a holistic theory of services would help to solve not only the theoretical and methodological problems that occur in this field, but also many practical questions that are determined by the specifics of the service as a commodity. These features often do not allow us to apply regulatory and legal documents to the service sector, which are quite effectively used to regulate commodity-money relations in the markets of traditional goods.

In this regard, it seems relevant and important to develop the methodological foundations of strategic marketing in the service sector, which could become a unifying principle of research in different subject areas and be, including a base for developing effective management mechanisms in the service sector.

Given the features of the service, we can distinguish the following characteristics of its provision:

- requirements for the service should be clearly defined as characteristics that can be monitored and evaluated by the consumer; 
- in most cases, service management and service delivery characteristics can only be achieved by providing management of the service delivery process.

The characteristic of a service or its delivery process can be quantified (measured) or qualitatively expressed (subject to quality comparison), depending on how and by whom the assessment is made by the service organization or the consumer.

Current classification in the service sector requires further specification and systematization, which makes it important to determine the main and secondary criteria for the classification of these services. The study of technological features of production in the service sector, the interconnection of services and materialized goods, the change in the ratio in the technological processes of material and non-tangible products, the sectoral features of the share in the final product of services or materialized goods are extremely topical. Such questions can not be solved without a theoretical interpretation of the essence of the service, however, their research has a largely applied value, because the specificity of production technology in the service sector, the resource component and the target setting directly determine the management and marketing system in the service sector.

Technological features of production of services are directly interrelated with the problems of the formation and establishment of standardization systems. The issues of unification, standardization and certification with regard to services can be attributed to the most difficult to develop. In modern publications devoted to services, a lot of attention is paid to quality management, the quality of service models are given, the stages of quality measurement are described using different techniques, but the question of what is the quality of the service is still topical.

When developing the methodology of the marketing strategy for the service sector, it is necessary to take into account the specific nature of this area of activity, which is determined by the technological process, objectives of the activity, resources and sources of financing, personnel policy, consumer segment, management techniques and marketing concepts, promotion and communication features, and often ownership.

Thus, the object of the methodology of strategic shadowing of the service sector should be the service itself, considered as a specific commodity and an object of economic activity with special properties; The subject is a complex of economic, managerial, organizational, financial, social relations arising in the process of production, promotion and consumption of the service. Subjects are both physical and legal entities involved in the process of socio-economic relations in the service sector.

\section{REFERENCES}

Assel G. (1999) Marketing: principles and strategy. Moscow: INFRA-M, 803 p. (In Russ).

Corsten H. (2001) Dienstleistungsm anagement. 4. Aufl., München. 468 p.

Gaydaenko, T.A. (2006) Marketingovoe upravlenie. Polniy kurs MBA. Printsipy upravlencheskih resheniy i rossiyskaya praktika / T.A. Gaydaenko. 2-nd edition., revised and expanded. M.: Eksmo, 496 p.(in Russ)

Grönroos C., Ojasalo K. (2004) Service productivity. Towards a conceptualization of the transformation of inputs into economic results in services. Journal of Business Research. (57: 4). P. 414-423.

Kotler Ph., Keller K.L. (2012) Marketing management. Pearson Education. 816 p. 
Lasshof B. (ed.) (2006) Produktivität von Dienstleistungen. Mitwirkung und Einfluss des Kunden. Dissertation, Fernuniversität Hagen, Wiesbaden. 267 S. DOI: 10.1007/978-3-8350-9084-2

Mironova, N.V. (2003) Differentiated approach to marketing services. Marketing and marketing research. No. 3. P. $10-18$.

Schneider B. (2000) In: Fisk R.P., Grove S.J., John J. (eds) Services marketing selfportraits: introspections, reflections, and glimpses from the experts. American Marketing Association. Chicago. P. $173-187$.

Uzbekistan in figures. (2017) State Committee of the Republic of Uzbekistan on Statistics. 45 p.

Walker O., Jr. Boyd H., Larshe J.-K. (2006) Marketingovaya strategiya: kurs MBA: translated from eng. M.: Vershina, 2006. 496 p. (In Russ).

(C) Ziyayeva M.M., 2018

\title{
Article history:
}

Received: 07 April 2018

Revised: 25 April 2018

Accepted: 06 May 2018

\section{For citation:}

Ziyayeva M. (2018) Peculiarities of formation of marketing strategy in the sphere of services of the Republic of Uzbekistan. RUDN Journal of Economics, 26 (2), 186-195. DOI: 10.22363/23132329-2018-26-2-186-195

\section{Bio Note:}

Ziyayeva Mukhtasar Mansurdzhanovna, Cand. Econ. Sci., scientific researcher, Tashkent State University of Economics Uzbekistan.COntact information: e-mail: mukhtasar_yuldasheva@mail. $\mathrm{ru}$

\section{ОСОБЕННОСТИ ФОРМИРОВАНИЯ МАРКЕТИНГОВОЙ СТРАТЕГИИ В СФЕРЕ УСЛУГ РЕСПУБЛИКИ УЗБЕКИСТАН}

\author{
М.М. Зияева \\ Ташкентский государственный экономический университет \\ Республика Узбекистан, 100003, Ташкент, ул. Ислама Каримова, 49
}

В статье рассматриваются методологические аспекты формирования маркетинговой стратегии в сфере услуг. Для классификации основных видов маркетинга был представлен обзор теоретической и эмпирической литературы по этому вопросу. Обзор показал, что существует множество различных факторов, таких как социальная среда, рыночные ограничения, поведение людей, перспективы времени, концентрация менеджеров, структура рынка, степень развития общества, которые могут влиять на формирование маркетинговой стратегии.

Ключевые слова: маркетинговая стратегия, маркетинг в сфере услуг, маркетинг услуг в Узбекистане, сравнение маркетинговых стратегий 


\section{История статьи:}

Дата поступления в редакцию: 07 апреля 2018

Дата принятия к печати: 0 мая 2018

\section{Для цитирования:}

Зияева M.M. Особенности формирования маркетинговой стратегии в сфере услуг Республики Узбекистан // Вестник Российского университета дружбы народов. Серия: Экономика. 2018. Т. 26. № 2. C. 186-195. DOI: 10.22363/2313-2329-2018-26-2-186-195

\section{Сведения об авторе:}

Зияева Мухтасар Мансурджановна, кандидат экономических наук, докторант, Ташкентский государственный экономический университет. Контактная информация: e-mail: mukhtasar_yuldasheva@mail.ru 